\title{
PENGARUH PERMAINAN GOBAK SODOR TERHADAP KEMAMPUAN MOTORIK KASAR ANAK USIA 5-6 TAHUN TK ABA TIRTAMULYA KECAMATAN MAKARTI JAYA
}

\author{
Elsia Ketty ${ }^{1}$, Dr.H. Syarwani Ahmad, M.M. ${ }^{2}$, \\ Dessi Andriani S.Pd.AUD,.M.M³ \\ Email: elsiaketty48@gmail.com¹, syarwani190@yahoo.co.id² , \\ dessiandriani@gmail.com³
}

\begin{abstract}
Abstrak: Penelitian ini bertujuan untuk mengetahui pengaruh permainan gobak sodor terhadap kemampuan motorik kasar anak kelompok B2 di TK ABA Tirtamulya Kecamatan Makarti Jaya. Jenis penelitian ini adalah penelitian kuantitatif eksperimen. Metode pengambilan sampel dalam penelitain ini adalah True Experimental Design. Hasil penelitian menunjukan bahwa adanya pengaruh permainan gobak sodor terhadap kemampuan motorik kasar anak usia 5-6 tahun di TK ABA Tirtamulya Kecamatan Makarti Jaya dengan perolehan data hasil tes awal (pretest) pada kelas eksperimen menunjukkan bahwa kemampuan motorik kasar anak memiliki nilai rata-rata sebesar 45,17. Kemudian setelah diberikan perlakuan (treatment) menggunakan permainan gobak sodor, peneliti melakukan tes akhir (posttest) menunjukkan bahwa kemampuan motorik kasar memiliki nilai rata-rata sebesar 84,17. Dan dari perhitungan uji normalitas diperoleh bahwa hasil tes awal (pretest) dan hasil tes akhir (posttest) berdistribusi normal yaitu untuk data hasil tes awal (pretest) sebesar -0,57 dan data hasil tes akhir (posttest) sebesar -0,26. Nilai tersebut terletak antara (-1) dan (1), maka data dengan tes awal (pretest) dapat dikatakan berdistribusi normal. Kemudian hasil dari perhitungan uji homogenitas diperoleh bahwa nilai $\mathrm{F}_{\text {hitung }}=2,068$ dan $\mathrm{F}_{\text {tabel }}=$ 4,49 yang berarti bahwa $F_{\text {titung }} \leq \mathrm{F}_{\text {tabel }}$ sehingga dapat dinyatakan bahwa varians-varians tersebut homogen. Selanjutnya, perhitungan dari uji hipotesis menunjukkan bahwa hasil dari perhitungan regresi $\hat{Y}=\mathrm{a}+\mathrm{bX}$ diperoleh bahwa data hasil tes awal (pretest) sebesar 139,65 dan data hasil tes akhir (posttest) sebesar 195,03 yang berarti data hasil tes akhir (posttest) lebih besar dari hasil tes awal (pretest). Selanjutnya, hasil dari perhitungan uji-t diperoleh nilai $t_{\text {hitung }}=2,96$ dan $t_{\text {tabel }}=2,10$ pada taraf signifikan $(\alpha)=0,05(5 \%)$, yang berarti bahwa Ho ditolak dan Ha diterima.
\end{abstract}

Kata Kunci: Motorik kasar, Gobak Sodor, Anak Usia Dini.

\section{PENDAHULUAN}

Pendidikan anak usia dini adalah suatu upaya pembinaan yang ditujukan kepada anak yang dilakukan melalui pemberian rangsangan pendidikan untuk membantu pertumbuhan dan perkembangan jasmani dan rohani agar anak memiliki kesiapan dalam memasuki pendidikan lebih lanjut.
Penyelenggaraan pendidikan anak usia dini dapat berlangsung secara formal, non formal, dan informal, tujuan penyelenggaraan pendidikan ini adalah untuk mencerdaskan anak bangsa supaya berkualitas dan bermutu, yaitu anak dapat berkembang sesuai dengan tingkat perkembangannya.

Pembelajaran anak usia dini khususnya TK harus mengacu pada 
karakteristik anak usia dini serta mempertimbangkan berbagai aspek prinsip belajar pada anak usia dini, yaitu: berangkat dari apa yang dibawa anak, belajar harus menantang bagi anak, belajar sambil bermain, penggunaan alam sebagai sumber belajar. Berdasarkan karakteristik anak usia dini, sikap sosial merupakan bagian yang paling mendominasi dalam proses pembelajaran dimana anak berinteraksi dengan guru dan teman sebayanya, dan orang-orang sekelilingnya.

Aspek perkembangan anak sangat penting dikembangkan sejak usia dini, aspek perkembangan tersebut mencakup perkembangan moral agama, aspek perkembangan bahasa, aspek perkembangan motorik, aspek perkembangan kognitif, aspek perkembangan sosial emosional, dan aspek perkembangan seni. Keenam aspek tersebut harus dikembangkan sesuai dengan tahap perkembangan usia pada anak, karena setiap aspek perkembangan saling berkaitan apabila ada satu aspek saja yang tidak sesuai dikhawatirkan dapat mempengaruhi aspek perkembangan lainnya. Aspek perkembangan pada anak sangat baik dirangsang atau distimulasi terutama pada aspek perkembangan motorik kasar.

Motorik kasar merupakan gerakan tubuh yang menggunakan otot-otot besar dengan menggunakan seluruh anggota tubuh. gerakan motorik kasar melibatkan aktivitas otot-otot besar seperti, otot tangan, otot kaki, dan seluruh tubuh anak, misalnya gerakan meloncat, berlari, melempar, melompat, memanjat, dan lain-lain. Adapun pentingnya perkembangan motorik kasar bagi perkembangan sosial emosional yaitu dengan kemampuan motorik kasar yang baik maka anak akan mempunyai rasa percaya diri yang besar, dan lingkungan teman-teman pun akan menerima anak tersebut, sehingga anak akan mudah bersosialisasi dengan temannya dengan rasa kepercayaan diri yang besar yang dimilikinya.

Sedangkan pentingnya perkembangan motorik kasar bagi perkembangan kognitifnya yaitu dengan aktivitas fisik yang dilakukan anak akan meningkatkan rasa ingin 
tahu anak terhadap benda-benda yang dijumpai anak. Keterampilan motorik kasar anak juga dapat menumbuhkan kreativitas dan imajinasi anak dan gerakan-gerakan yang dilakukan akan bermanfaat untuk membuat fungsi belahan otak kanan dan otak kiri anak menjadi seimbang.

Untuk menstimulasi perkembangan motorik kasar pada anak dapat melakukan kegitan bermain gobak sodor, permainan ini dapat melatih motorik kasar anak dan juga menumbuhkan jiwa sosial pada anak, diharapkan permainan gobak sodor menjadi solusi alternatif untuk meningkatkan kemampuan gerak motorik kasar anak. Permainan gobak sodor mengalami keterpurukan dalam dekade belakangan ini, hal ini dipengaruhi oleh perkembangan pola pikir dari masyarakat yang semakin maju sehingga meninggalkan kebiasaankebiasaan lama yang masih tradisional. Permainan gobak sodor jarang sekali dimainkan, bahkan anak di masa sekarang ini banyak yang tidak tahu cara bermain gobak sodor.
Permainan gobak sodor merupakan salah satu permainan yang jarang sekali dimainkan oleh anak-anak. Permainan ini sangat menarik, menyenangkan, sekaligus sangat sulit karena setiap orang harus terjaga dan berlari secepat mungkin untuk meraih kemenangan. Oleh karena itu peneliti ini menggunakan permainan gobak sodor untuk mengetahui perkembangan motorik kasar anak.

Namun fakta di lapangan, terlihat hasil observasi kelompok B di TK ABA Tirtamulya Kecamatan Makarti Jaya yang menjadi subjek dalam penelitian ini, menunjukan bahwa kemampuan motorik kasar anak belum berkembang secara optimal, hal ini dapat dilihat ketika anak bermain gobak sodor anak mengalami kesulitan untuk belari, meloncat, dan menjaga keseimbangan tubuh, pada saat melakukan kegitan bermain gobak sodor dan terdapat beberapa anak yang lambat dalam berlari dan anak merasa kelelahan saat bermain gobak sodor, tedapat beberapa anak juga yang yang kurang bisa menjaga keseimbangan dalam melakukan 
permainan ini, hal ini dikarenakan kurang terbiasanya anak melakukan kegiatan-kegiatan yang dilakukan dengan menggunakan motorik kasar. Berdasarkan observasi yang peneliti lakukan, peneliti menemukan fakta bahwa anak kelompok B yang berjumlah 18 anak, 11 anak diantaranya dapat dikatakan bahwa kemampuan motorik kasar anak masih belum berkembang dan 7 anak yang berkembang sesuai harapan. Hal ini disebabkan kurangnya aktivitas bermain gobak sodor dalam pembelajaran motorik kasar anak.

Seperti halnya dengan penelitian yang dilakukan oleh Iswantiningtyas dan Wijaya Tahun (2015) dengan judul "Meningkatkan Kemampuan Motorik Kasar Anak Usia Dini melalui Permainan Tradisional Gobak Sodor" bahwa permainan gobak sodor dapat meningkatkan kemampuan motorik kasar anak. Hal ini dapat dilihat dari hasil penelitian pada siklus I 35\%, siklus II 55\%, sedangkan pada siklus III $85 \%$. Hal ini dapat disimpulkan bahwa penerapan permainan gobak sodor dalam pembelajaran dapat meningkatkan kemampuan motorik kasar anak usia dini.

Berdasarkan latar belakang di atas, peneliti tertarik untuk melakukan penelitian tentang perkembangan motorik kasar anak dengan menggunakan permainan gobak sodor. Peneliti yang dilakukan di TK ABA Tirtamulya Kecamata Makarti Jaya dengan judul “ Pengaruh Permainan Gobak Sodor Terhadap Kemampuan Motorik Kasar Anak Usia 5-6 Tahun Kelas B TK ABA Tirtamulya Kecamatan Makarti Jaya ".

\section{TINJAUAN PUSTAKA}

\section{Pengertian Permainan}

Permainan adalah suatu aktivitas yang menyenangkan bagi anak dan membuat anak senang untuk memainkan permainan tersebut. Menurut Santrock 1995 dalam Kurniati (2016:1) permainan (play) ialah suatu kegiatan yang menyenangkan yang dilaksanakan untuk kepentingan kegiatan itu sendiri. Permainan merupakan suatu kreativitas bermain yang di dalamnya telah memiliki aturan yang jelas dan disepakati bersama. 
Sedangkan menurut Suyadi dkk, (2015:34) bahwa bagi anak, permainan adalah sesuatu yang menyenangkan suka rela, penuh arti, dan aktivitas spontan. Permainan juga sering dianggap kreatif, yang menyertakan pemecahan masalah, belajar keterampilan sosial baru, bahasa, baru dan keterampilan fisik yang baru.

Adapun menurut Desmita (2015:141) permainan adalah salah satu bentuk aktivitas sosial yang dominan pada awal masa anak-anak. Sebab anak-anak menghabiskan lebih banyak waktunya di luar rumah bermain dengan teman-temannya di banding terlibat aktivitas lain. Karena itu kebanyakan hubungan teman sebaya dalam masa ini terjadi dalam benntuk permainan. Jadi permainan bagi anak adalah suatu bentuk aktivitas yang menyenangkan yang dilakukan semata-maata untuk anak itu sendiri, bukan karena ingin memperoleh sesuatu yang dihasilkan dari aktivitas tersebut.

Dari beberapa pendapat di atas dapat disimpulkan bahwa permainan adalah suatu aktivitas yang menyenangkan untuk mendapatkan kesenangan bagi anak itu sendiri, dan membuat anak dapat saling bersosialisasi dan interaksi kepada temannya. Karena itu kebanyakan hubungan teman sebaya dalam masa ini terjadi dalam bentuk permainan.

\section{Pengertian Gobak Sodor}

Gobak sodor adalah suatu permainan tradisional yang sangat menyenangkan saat dimainkan, menurut Mulyani (2013:58) gobak sodor adalah permainan tradisional yang merupakan jenis permainan grup yang terdiri dari dua regu, dimana masing-masing regu terdiri dari 3-5 orang. Permainan ini memerlukan tempat yang cukup luas karena digunakan untuk berkejaran.

Sedangkan menurut $\mathrm{Fe}$ (2017:49) gobak sodor adalah permainan tradisonal ini dimainkan secara beregu di lapangan. Biasanya, dimainkan dilapangan yang ditandai dengan garis persegi. Tujuan permainan ini adalah menghadang lawan agar tidak berhasil bolakbalik. Regu penjaga garis akan 
berjaga di tiap garis vertikal maupun horizontal. Sedangkan regu pemain berusaha melewati garis dengan sigap agar tidak tersentuh penjaga. Permainan ini membutuhkan kecepatan berlari, strategi, dan kerja sama tim yang baik.

Adapun menurut Iswaningtyas (2015:249) permainan gobak sodor merupakan permainan tradisonal yang sudah jarang dimainkan oleh anak-anak. Permainan ini sangat menarik, menyenangkan, sekaligus sangat sulit karena setiap orang harus selalu terjaga dan berlari secepat mungkin untuk meraih kemenangan.

Dari beberapa pendapat di atas dapat disimpulkan bahwa gobak sodor adalah permainan yang di lakukan dari dua regu yang terdiri dari 3-5 orang yang membutuhkan kecepatan lari, kerja sama, dan strategi untuk meraih kemenangan. Permainan ini sangat menarik, menyenangkan, sekaligus sangat sulit karena setiap orang harus selalu terjaga dan berlari secepat mungkin untuk meraih kemenangan.

\section{Pengertian Motorik Kasar}

Kemampuan motorik kasar merupakan suatu kemampuan yang di miliki seseorang dengan menggunakan otot-otot besar, menurut Suryana (2018:153) Kemampuan motorik kasar adalah gerakan tubuh yang menggunakan gerakan otot-otot besar atau sebagian besar atau seluruh anggota tubuh yang dipengaruhi oleh kematangan anak itu sendiri, contohnya kemampuan duduk, menendang, berlari dan naik turun tangga. Adapun menurut Samsudin (2008: 9) kemampuan motorik kasar adalah kemampuan anak TK beraktivitas dengan menggunakan otot-otot besar.

Selanjutnya menurut Rohmah (2013:3) kemampuan motorik kasar adalah kemampuan gerakan yang dimotori atau dikendalikan keseluruh anggota badan seperti olahraga, gerak ayunan, gerak naik turun tangga, lari-lari kecil, melompat melempar, menendang yang mampu melakukan aktivitas fisik secara terkoordinasi dalam melatih kelenturan, keseimbangan, dan kelincahan. 
Dari beberapa pendapat di atas dapat disimpulkan bahwa pengertian kemampuan motorik kasar adalah gerakan koordinasi yang menggunakan otot-otot besar menggunakan seluruh anggota tubuh utuk melakukan suatu gerakan misalnya, meloncat, berlari, melempar, memanjat, dan lain-lain. Pada dasarnya motorik kasar ini sering menggunakan otot tangan, kaki, dan seluruh anggota tubuh untuk bergerak.

\section{METODOLOGI PENELITIAN}

Menurut Sugiyono metode penelitian pendidikan adalah cara ilmiah untuk mendapatkan data yang valid dengan tujuan dapat ditemukan, dikembangkan, dan dibuktikan, suatu pengetahuan tertentu sehingga pada gilirannya dapat digunakan untuk memahami, memecahkan dan mengantisipasi masalah dalam bidang pendidikan. Metode yang digunakan dalam penelitian ini adalah metode eksperimen yaitu metode yang digunakan untuk mencari perlakuan tertentu. Penelitian ini menggunakan true experimental design yaitu dengan desain posttes-only control design. Menurut Sugiyono (2017:112) true experimental design merupakan eksperimen yang betulbetul karena dalam desain ini, peneliti dapat mengontrol semua variabel yang mempengaruhi jalannya eksperimen. Dengan demikian valid internal (kualitas pelaksanaan rancangan penelitian) dapat menjadi tinggi. Ciri utama dari true eksperimental adalah bahwa sampel yang digunakan untuk eksperimen maupun sebagai kelompok kontrol di ambil secara random dari populasi tertentu.

Posstest-only control design merupakan bentuk true eksperimental design yang digunakan dalam penelitian ini, yaitu dalam design ini terdapat dua kelompok yang masing-masing di pilih secara random (R). kelompok pertama di beri perlakuan (X) dan kelompok yang lain tidak. Kelompok yang diberi perlakuan disebut kelompok eksperimen dan kelompok yang tidak di beri perlakuan disebut kelompok kontrol.

Penelitian ini dilaksanakan pada tahun 2019 di TK ABA Tirtamulya 
Kecamatan Makarti Jaya, yaitu pada bulan September sampai Oktober semester genap tahun ajaran 2019/2020. Penentuan waktu ini mengacu pada kalender akademik yang ada di sekolah.

Adapun yang menjadi populasi dalam penelitian ini adalah anak kelas B2 TK ABA Tirtamulya Kecamatan Makarti Jaya yang berjumlah 37 Anak. Adapun yang menjadi populasi dalam penelitian ini adalah anak kelas B2 TK ABA Tirtamulya Kecamatan Makarti Jaya yang berjumlah 37 Anak.

Teknik pengumpulan data yang digunakan dalam penelitian ini yaitu observasi dan dokumentasi. Selanjutnya adapun teknik analisis yang digunakan dalam penelitian ini yaitu uji normalitas, uji homogenitas, dan uji hipotesis. Kriteria pengujian hipotesis dalam penelitian ini adalah: Jika $t_{\text {hitung }}>t_{\text {tabel }}$ maka Ho ditolak, Ha diterima

Jika $\mathrm{t}_{\text {hitung }} \leq \mathrm{t}_{\text {tabel }}$ maka Ho diterima, Ha ditolak

Ho : Permainan gobak sodor tidak memiliki pengaruh terhadap kemampuan motorik kasar anak usia
5-6 tahun kelompok B2 Tirtamulya Kecamatan Makarti Jaya.

$\mathrm{Ha}$ : Permainan gobak sodor memiliki pengaruh terhadap kemampuan motorik kasar anak usia 5-6 tahun kelompok B2 di TK ABA Tirtamulya Kecamatan Makarti Jaya. Dengan kriteria pengujian hipotesis, yaitu jika thitung lebih besar dari $t_{\text {tabel }}$ dengan taraf signifikan $(\alpha)=$ 0,05 maka dapat disimpulkan bahwa Ha diterima, sebaliknya jika thitung lebih kecil dari tabel maka Ha ditolak.

\section{HASIL DAN PEMBAHASAN}

Dalam penelitian ini digunakan instrumen penelitian berupa lembar observasi untuk mengetahui bahwa rata-rata kemampuan motorik kasar anak dengan tes akhir (posttest) lebih tinggi dibandingkan dengan hasil tes awal (pretest) dimana nilai rata-rata hasil tes akhir (postest) 84,17. Sedangkan nilai rata-rata hasil tes akhir (pretest) 45,17. Sedangkan di kelas kontrol hasil awal (pretest) sebesar 30,6 dan hasil tes akhir (posttest) sebesar 80,4. Hal ini menunjukkan bahwa rata-rata hasil tes akhir (posttest) kelas eksperimen 
lebih besar dari pada kelas kontrol, artinya pembelajaran kemampuan motorik kasar menggunakan permainan gobak sodor memiliki pengaruh dibandingkan menggunakan metode pembelajaran yang biasa diterapkan oleh gurunya yaitu dengan kegiatan dalam kelas.

\section{Berdasarkan perhitungan} yang di dapat untuk posttest $-0,26$, uji normalitas data yang diperoleh adalah dan pretest diperoleh -0,57. Harga tersebut terletak antara (-1) dan (1) sehingga dapat dikatakan bahwa data kedua kelas tersebut terdistribusi normal. Kemudian hasil perhitungan uji normalitas data untuk $F_{\text {hitung }} \leq \mathrm{F}_{\text {tabel }} \quad 2,068 \leq 4,49$ maka varians-varians dinyatakan homogen. Selanjutnya satelah pengujian normalitas data dan homogenitas data dilakukan dan dinyatakan data tersebut terdisribusi normal dan varians dalam peneltian tersebut homogen, maka tahapan berikutnya dilakukan pengujian hipotesis dari hasil perhitungan uji-t diatas diperoleh $\quad t_{\text {hitung }}=2,96$ jika dibandingkan dengan $\mathrm{t}_{\text {tabel }} 18$ adalah 2,10 adalah berarti Ho ditolak dan
Ha diterima, maka dari itu hipotesis penel itian ini terdapat pengaruh signifikan permainan gobak sodor terhadap kemampuan motorik kasar pada anak kelompok B2 di TK ABA Tirtamulya Kecamatan Makarti Jaya. Berdasarkan penerapannya di kelas, pembelajaran menggunakan permainan gobak sodor untuk menunjukkan perubahan sangat baik terhadap kemampuan motorik kasar kelas B2 TK ABA Tirtamulya Kecamatan Makarti Jaya. Melihat dari teori dan kajian terdahulu yang relevan di atas dengan hasil dari penelitian yang dilakukan oleh Erdiana Tahun (2016) dimana pengaruh permainan tradisional gobak sodor terhadap perkembangan motorik kasar dan sikap koopertif. Sedikit berbeda dengan penelitian yang peneliti lakukan dimana peneliti mengambil penelitian dengan judul pengaruh permainan gobak sodor terhadap kemampuan motorik kasar anak, artinya penelitian yang dilakukan yang sama hanya pada variabel terikatnya yaitu kemampuan motorik kasar. Dari penelitian yang peneliti lakukan bahwa permainan gobak sodor 
mempunyai pengaruh terhadap kemampuan motorik kasar pada anak kelompok B2 di TK ABA Tirtamulya Kecamatan Makarti Jaya, dan dapat dibuktikan kebenarannya.

\section{KESIMPULAN DAN SARAN}

Berdasarkan hasil penelitian yang peneliti lakukan di TK ABA Tirtamulya Kecamatan Makarti Jaya dapat disimpulkan bahwa untuk menjawab rumusan masalah dalam penelitian ini yaitu sebelum diberikan perlakuan (treatment) melalui permainan gobak sodor, kemampuan motorik kasar pada anak masih belum berkembang. Hal ini terlihat dari hasil tes awal (pretest) yang dilakukan oleh peneliti. Hasil tes awal (pretest) pada kelas eksperimen menunjukkan bahwa kemampuan motorik kasar anak memiliki nilai rata-rata sebesar 45,17. Kemudian setelah diberikan perlakuan (treatment) sebanyak 6 kali pertemuan menggunakan permainan gobak sodor, peneliti melakukan tes akhir (posttest) untuk mengetahui adanya pengaruh dari permainan gobak sodor terhadap kemampuan motorik kasar pada anak. Hasil tes akhir (posttest) menunjukkan bahwa kemampuan motorik kasar memiliki nilai ratarata sebesar 84,17.

Dan dari perhitungan uji normalitas diperoleh bahwa hasil tes awal (pretest) dan hasil tes akhir (posttest) berdistribusi normal yaitu untuk data hasil tes awal (pretest) sebesar -0,57 dan data hasil tes akhir (posttest) sebesar -0,26. Nilai tersebut terletak antara (-1) dan (1), maka data dengan tes awal (pretest) dapat dikatakan berdistribusi normal. Kemudian hasil dari perhitungan uji homogenitas diperoleh bahwa nilai $F_{\text {hitung }}=2,068$ dan $\mathrm{F}_{\text {tabel }}=4,49$ yang berarti bahwa $F_{\text {titung }} \leq F_{\text {tabel }}$ sehingga dapat dinyatakan bahwa varians-varians tersebut homogen. Selanjutnya, perhitungan dari uji hipotesis menunjukkan bahwa hasil dari perhitungan regresi $\hat{Y}=a+b X$ diperoleh bahwa data hasil tes awal (pretest) sebesar 139,65 dan data hasil tes akhir (posttest) sebesar 195,03 yang berarti data hasil tes akhir (posttest) lebih besar dari hasil tes awal (pretest). Selanjutnya, hasil 
dari perhitungan uji-t diperoleh nilai $\mathrm{t}_{\text {hitung }}=2,96$ dan $\mathrm{t}_{\text {tabel }}=2,10$ pada taraf signifikan $(\alpha)=0,05(5 \%)$, yang berarti bahwa Ho ditolak dan Ha diterima. Maka dari itu hipotesis penelitian ini terdapat pengaruh yang signifikan dengan menggunakan permainan gobak sodor terhadap kemampuan motorik kasar pada anak usia 5-6 tahun kelompok B2 di TK ABA Tirtamulya Kecamatan Makarti Jaya.

Berdasarkan kesimpulan yang telah dipaparkan, maka peneliti memberikan saran untuk:

1) Sekolah

Permainan gobak sodor dapat dijadikan sebagai sebuah strategi dalam pembelajaran yang dapat memotivasi anak untuk melatih kemampuan motorik kasar anak dan sebagai salah satu alternatif untuk meningkatkan mutu pemelajaran yang ada di sekolah.

2) Guru

Memberikan pengalaman kepada guru dalam proses pembelajaran dengan menggunakan permainan gobak sodor terhadap kemampuan motorik kasar pada anak.

3) Orang Tua

Orang tua diharapkan
menyediakan waktu luang untuk
melatih kemampuan motorik kasar
pada anak melalui permainan gobak
sodor sehingga dapat membantu
mengoptimalkan kemampuan
motorik kasar pada anak.

\section{DAFTAR PUSTAKA}

Desmita, 2015. Psikologi Perkembangan, Bandung: $\mathrm{Pt}$ Remaja Rosdakarya.

Erdiana, Lita. 2016, Pengaruh Permainan Gobak Sodor Terhadap Perkembangan Motorik Kasar Dan Sikap Kooperatif Anak TK Kelompok B Di Kecamatan Sidoarjo, Vol 2 No. 3(agustus 2016) Diakses pada 13 Maret 2019.

Fe, Eci. 2017, Buku Pintar Olahraga \& Permainan Tadisional, Jakarta Selatan: Laksana.

Iswaningtyas, Veny \& Wijaya,Intan. 2015, Meningkatkan Kemampuan Motorik Kasar Anak Usia dini melalui permainan Tradisional Gobak Sodor, Vol 1 No. 3(oktober 2015) Diakses pada 15 Februari 2019. 
Kurniati, Euis. 2016, Permainan Tradisional dan Perannya dalam Mengembangakan keterampilan sosial anak. Jakarta: Prenamadia Group.

Mulyani, Sri. 2013. 45 Permainan Tradisona Anak Indonesia. Yogyakarta: Langensari Publishing.

Rohmah, Muzilatur A \& Astini, Made. 2013, Peran Kegiatan Tari Untuk Mengembangkan Kemampuan Motorik Kasar Anak Kelompok B Di TK Muslimat Di T Muslimat Mazraatul Ulum II Paciran Lamongan, Vol 2, Nomor 1. Diakses pada 17 Februari 2019.

Samsudin, 2008. Pembelajaran Motorik Di Taman Kanakkanak, Jakarta: PT Fajar Interpratama.

Sugiyono. 2017, Metode Penelitian Pendidikan. Bandung: Alfabeta.

Suryana, Dadan. 2018, Stimulasi Dan Aspek Perkembangan Anak. Jakarta: Prenadamedia Group.

Suyadi, \& Ulfah, Maulidya. 2015, Konsep Dasar Puad. Bandung: Pt Remaja Rosdakarya. 